\title{
Evaluation of DAVIH-BLOT System for Simultaneous Diagnosis of HIV-1/2
}

Otto Cruz Sui ${ }^{1 *}$, Dervel Felipe Díaz Herrera ${ }^{2}$, Lucy Montano Tamayo ${ }^{3}$, Kenia Romero Martínez ${ }^{2}$, María Teresa Pérez Guevara ${ }^{4}$ and Eladio Silva Cabrera ${ }^{5}$

${ }^{1}$ Biologist, MSc degree in Biochemistry, Health Sciences PhD, Senior Researcher, AIDS Research Laboratory, Cuba

${ }^{2}$ Biochemistry, MSc degree in Biochemistry, Adjunct Researcher, AIDS Research Laboratory, Cuba

${ }^{3}$ Chemical Analysis Technician, AIDS Research Laboratory, Cuba

${ }^{4}$ Biochemistry, MSc degree in Biochemistry, Associate Researcher, Jamaica

${ }^{5}$ Specialist II degree in Microbiology, Veterinary Sciences PhD, Senior Researcher, AIDS Research Laboratory, Cuba

\begin{abstract}
Descriptors: Western blot, HIV-1/2, diagnosis.

Validation of performance characteristics of HIV diagnostic tests is one of the main demands of regulatory bodies. Evaluating of diagnostics tests prior to use avoid errors with a high economic and social cost. The aim of the work was to validate the DAVIH-BLOT modified system for simultaneous diagnosis of HIV-1/2. An evaluation with 166 samples of reference panels and a comparative study against a commercial kit of similar characteristics with an international reference panel of 25 samples was made. The new system expanded its diagnostic capacity with the incorporation of a gp36 synthetic peptide-protein conjugate, obtaining high results of sensitivity and specificity in the performance evaluation (99.18 and $76.74 \%$ respectively). In the comparative study with the analogue system the concordance was very good (kappa=1). The inclusion of the synthetic peptide and natural proteins in the same solid phase, constitute a technological novelty to this assay. The application of this test, allows a short cut of the diagnostic algorithm when are used screening tests for HIV-1 and 2 as in the Cuba's diagnostic algorithm.
\end{abstract}

\section{Introduction}

Technological development for the diagnosis of HIV infection during over two decades, has favored the incorporation of modifications in the Western blot assays (WB) that are routinely used as confirmatory tests [1]. Currently, synthetic peptides of HIV-2 gp36 in the same nitrocellulose solid phase where are previously fixed natural antigens of HIV-1 could be incorporated, which increases the diagnostic possibilities to identify and differentiate simultaneously by HIV-1 and HIV-2 infection [2].

In the AIDS Research Laboratory (LISIDA, its Spanish acronym), a WB system for the detection of antibodies against HIV-1 (DAVIHBLOT) was developed and registered according to the regulations of the Center for the State Control of Drugs Quality [3]. In Cuba, this WB was officially introduced in the algorithm like a supplementary technique to confirm the diagnosis of HIV infection in the control program for HIV/ AIDS, which initially only included HIV-1 screening [4].

According to the National HIV/AIDS Program (full title: National Program for Prevention and Control of Sexually-Transmitted Infections and HIV/AIDS), the first HIV-2 case was diagnosed in 1987 and to December 2011, had been 20 cases confirmed, three patients of them now deceased (National Epidemiology Division, Ministry of Public Health, unpublished data). Presence of HIV-2 in Cuba, required to introduction of mixed HIV-1/2 screening assays in the algorithm of diagnostic network of the National Program against HIV/AIDS [5-8].

In Cuban HIV-1/2 diagnostic algorithm, double reactive samples by screening assays are confirmed by DAVIH-BLOT (Western blot system for HIV-1 diagnosis), so it's handicap is to continue searching the negative and indeterminate results in this assay, to discriminate possible HIV-2 infection among their possible causes. Nowadays, our algorithm includes an HIV-2 specific ELISA and after that, we apply a HIV-2 WB if the result is positive. That's why introduction of a Western blot that allows confirmation of HIV-1 and a presumptive diagnose of HIV-2 infection simultaneously could simplify this process [8].

According to this, the solid phase of DAVIH-BLOT system had modified by incorporating a synthetic peptide of HIV-2 gp 36 . The objective of this study is to validate the performance characteristic of the new test in Cuban condition, as recommended by many authors [9-11].

\section{Methods and Materials}

\section{Reference panels}

Seven sera reference panel of different geographical areas were taking to study the diagnostic sensitivity and specificity as such as analytical specificity. Four belonged to World Health Organization and three characterized by LISIDA.

WHO panel composed by ARP $512(\mathrm{G})$ with eight HIV-1 positive samples, ARP 508 (F-UK) with eight HIV-1 positive samples, panel A with four HIV-2 positive samples and panel C with six HIV-2 positive samples. These panels came from HIV-1/2 endemic areas (Table 1).

Panel samples of LISIDA had characterized according the diagnostic strategy proposed by the WHO for countries with low prevalence of HIV-1/2 infection [12]. First of all, HIV-1/2 antibody screening is done with the ultra micro analytical system UMELISA HIV $1+2$ recombinant (TecnoSuma, Ciudad Habana, Cuba) and Vironostika, Uniform II Ag/ Ac VIH 1 y 2 (Biomérieux, Holanda). Reactive samples are confirmed by HIV-1 WB (DAVIH-BLOT, DAVIH Laboratories, Cuba). Panel 1 of

*Corresponding author: Otto Cruz Sui, Health Sciences, Senior Researcher AIDS Research laboratory (lisida), laboratorios davih, Tapaste Road and National Highway, Cuba, Tel: 047-848700, 047-848727; E-mail: cicdc@infomed.sld.cu; ocruz@infomed.sld.cu

Received June 08, 2011; Accepted September 21, 2012; Published September 24, 2012

Citation: Sui OC, Herrera DFD, Tamayo LM, Martínez KR, Guevara MTP, et al. (2013) Evaluation of DAVIH-BLOT System for Simultaneous Diagnosis of HIV-1/2. J AIDS Clinic Res S1: 020. doi:10.4172/2155-6113.S1-020

Copyright: (C) 2013 Sui OC, et al. This is an open-access article distributed unde the terms of the Creative Commons Attribution License, which permits unrestricted use, distribution, and reproduction in any medium, provided the original author and source are credited. 
Citation: Sui OC, Herrera DFD, Tamayo LM, Martínez KR, Guevara MTP, et al. (2013) Evaluation of DAVIH-BLOT System for Simultaneous Diagnosis of HIV-1/2. J AIDS Clinic Res S1: 020. doi:10.4172/2155-6113.S1-020

\begin{tabular}{|c|c|c|c|}
\hline & Code & Source & Reactivity to HIV-2 \\
\hline Panel C & 1A-P372SD & Senegal & Positive \\
\hline Panel C & $7 G-1337$ SL & Senegal & Positive \\
\hline Panel C & 20541 & Ivory Coast & Positive \\
\hline Panel C & 13509 & Ivory Coast & Positive \\
\hline Panel C & 7321 & Guinea Bissau & Positive \\
\hline Panel C & 7364 & Guinea Bissau & Positive \\
\hline Panel A & 22051 & Ivory Coast & Positive \\
\hline Panel A & 7318 & Guinea Bissau & Positive \\
\hline Panel A & 7358 & Guinea Bissau & Positive \\
\hline Panel A & $8 \mathrm{H}-1166$ & Senegal & Positive \\
\hline
\end{tabular}

Table 1: Characteristics of the A and $C$ panels from World Health Organization.

\begin{tabular}{|c|c|c|c|}
\hline & \multicolumn{3}{|c|}{ Relation sample's condition to infection } \\
\hline \multirow{3}{*}{ DAVIH BLOT-VIH-1/2 } & & Positive & Negative \\
\hline & Positive & a & $\mathrm{b}$ \\
\hline & Negative & c & $d$ \\
\hline
\end{tabular}

Legend: a: True positives (TP); b: False positives (FP); c: False negatives (FN); d: True negatives $(T N)$; Sensitivity $=a / a+c$; Specificity $=d / b+d$.

Table 2: To calculate the performance parameters of WB assay, results were processed according the following table.

LISIDA included 46 samples; of them 23 were HIV-2 positives, $6 \mathrm{HIV}$ 1 positives, $2 \mathrm{HIV}-1 / 2$ positives and 15 negatives. Panel 2 included 78 HIV-1 positives and panel 3 with 16 negatives samples.

\section{Evaluation of DAVIH-BLOT HIV-1/2 using reference panels}

All samples were analyzed with the DAVIH-BLOT VIH-1/2 system.

To calculate the performance parameters of WB assay, results were processed (Table 2).

Diagnostic sensitivity and specificity were estimated according to the above description. Analytical specificity was used to measure crossreactivity of HIV-1 positives samples to HIV-2 gp36 synthetic peptide, fixed in the solid phase. It was calculated using the described formula for diagnostic specificity.

The verisimilitude ratio $[13,14]$, which measure how probable more is a concrete result (positive or negative) according the presence or absence of disease. It does not depend on the prevalence and it's defined itself like:

Positive verisimilitude: It is calculated dividing the probability of positive result in infected patients between the probabilities of positive result among the healthy. It is the quotient between fraction of true positives (sensitivity) and fraction of false positives (1-specificity):

Positive verisimilitude ratio=Sensitivity/1-Specificity

Negative verisimilitude: It is calculated dividing the probability of negative result in presence of illness between probabilities of negative result in absence of it. It is the quotient between fraction of false negatives (1-sensitivity) and fraction of true negatives (specificity).

Negative verisimilitude ratio $=1$-Sensitivity/Specificity

\section{Comparative study between DAVIH-BLOT HIV-1/2 system and a commercial diagnostic kit}

DAVIH-BLOT HIV-1/2 and the commercial system "HIVBLOT 2.2" of Genelabs Diagnostic (Science Park, Singapore) were compared with the "Worldwide HIV Performance Panel WWRB 302 (M)", of Boston Biomedica, Inc; consisting of 25 characterized samples according Table
3. Kappa index was calculated to determine the concordance between them. Relative sensitivity and specificity of DAVIH-BLOT VIH-1/2 were calculated, using as a pattern of comparison the commercial kit results.

Kappa index: It is a concordance test based on the comparison of expected concordance index ( $p e$ ) with observed concordance index [15]. It is calculated as follows:

Concordance (kappa index)

$$
k=\frac{(p o-p e)}{(1-p e)}
$$

Where:

$$
\begin{aligned}
& \text { po }=\frac{(\mathrm{a}+\mathrm{d})}{\left(\mathrm{P}^{n} \mathrm{~N}\right)} \\
& \text { pe } \underline{ }
\end{aligned}
$$

$\mathrm{N}=\mathrm{a}+\mathrm{b}+\mathrm{c}+\mathrm{d}$

Concordance in the Positive case $\mathrm{P}=\{(\mathrm{a}+\mathrm{b}) / \mathrm{n} \times(\mathrm{a}+\mathrm{c}) / \mathrm{n}\} \times \mathrm{n}$

Concordance in the Negative case $\mathrm{N}=(\mathrm{c}+\mathrm{d})-\{(\mathrm{a}+\mathrm{c})-\mathrm{P}\}$

The results were classified into five groups [15]:

Deficient concordance: $\kappa<0.2$

Regular concordance: $0.21<\kappa<0.4$

Moderate concordance: $0.41<\kappa<0.6$

\begin{tabular}{|c|c|c|c|}
\hline Code & Origin & Genotype & $\begin{array}{l}\text { Genelabs Diagnostics } \\
\text { HIVBLOT2.2" }\end{array}$ \\
\hline WWRB302(M)-01 & Spain & $\mathrm{O}$ & $31,51 / 55,65,160$ \\
\hline WWRB302(M)-02 & Ghana & A & $18,24,31,41,51 / 55,65,120,160$ \\
\hline WWRB302(M)-03 & Ghana & G & $18,24,31,41,51 / 55,65,120,160$ \\
\hline WWRB302(M)-04 & Ghana & G & $18,24,31,41,51 / 55,65,120,160$ \\
\hline WWRB302(M)-05 & Ghana & A & $18,24,31,41,51 / 55,65,120,160$ \\
\hline WWRB302(M)-06 & Ghana & G & $24,31,41,51 / 55,65,120,160$ \\
\hline WWRB302(M)-08 & Ivory Coast & G & $\begin{array}{l}\text { gp36, 18, 24, 31, 41, 51/55, } 65 \\
120,160\end{array}$ \\
\hline WWRB302(M)-09 & Ivory Coast & A & $24,31,41,51 / 55,65,120,160$ \\
\hline WWRB302(M)-10 & Ivory Coast & Negative & No bands \\
\hline WWRB302(M)-11 & Mozambique & VIH-2 & gp36, 24 \\
\hline WWRB302(M)-12 & Mozambique & C & $24,31,41,51 / 55,65$ \\
\hline WWRB302(M)-14 & Uganda & D & $24,31,41,51 / 55,65,120,160$ \\
\hline WWRB302(M)-15 & Uganda & D & $18,24,31,41,51 / 55,65,120,160$ \\
\hline WWRB302(M)-16 & Uganda & D & $18,24,31,41,51 / 55,65,120,160$ \\
\hline WWRB302(M)-17 & Uganda & D & $18,24,31,41,51 / 55,65,120,160$ \\
\hline WWRB302(M)-19 & Zimbabwe & C & $18,24,31,41,51 / 55,65,120,160$ \\
\hline WWRB302(M)-21 & China & B & $18,24,31,41,51 / 55,65,120,160$ \\
\hline WWRB302(M)-22 & Thailand & E & $18,24,31,41,51 / 55,65,120,160$ \\
\hline WWRB302(M)-24 & Thailand & $\mathrm{E}$ & $18,24,31,41,51 / 55,65,120,160$ \\
\hline WWRB302(M)-25 & India & VIH-2 & gp36, 24, 31, 160 \\
\hline WWRB302(M)-26 & USA & B & $18,24,31,41,51 / 55,65,120,160$ \\
\hline WWRB302(M)-27 & USA & $B / D$ & $18,24,31,41,51 / 55,65,120,160$ \\
\hline WWRB302(M)-28 & Argentina & $\mathrm{F}$ & $18,24,31,41,51 / 55,65,120,160$ \\
\hline WWRB302(M)-29 & Argentina & B & $18,24,31,41,51 / 55,65,120,160$ \\
\hline /WRB302(M)-30 & Argentina & Negative & No Danas \\
\hline
\end{tabular}

Good concordance: $0.61<\kappa<0.8$

Very Good concordance: $0.81<\kappa<1.0$

Table 3: Characteristics of the $\mathrm{BB}^{\circledR}$ panel: "Worldwide HIV Performance Pane WWRB $302(\mathrm{M})$ ", with the referral results of bands reactivity by Genelabs Diagnostics system "WB HIVBLOT2.2". 
Citation: Sui OC, Herrera DFD, Tamayo LM, Martínez KR, Guevara MTP, et al. (2013) Evaluation of DAVIH-BLOT System for Simultaneous Diagnosis of HIV-1/2. J AIDS Clinic Res S1: 020. doi:10.4172/2155-6113.S1-020

Page 3 of 5

DAVIH BLOT VIH 1/2. System for the detection of antibodies to Human Immunodeficiency Virus type 1 and 2 (HIV$1 / 2$ ) in serum or plasma

First, serum samples were diluted 1:100 in sample dilution buffer plus $5 \%$ of skimmed milk and added to sensitized strips. Next, incubate from 18 to 20 hours at room temperature and wash strips with phosphate buffer saline-tween 20 . Then, horseradish peroxidase conjugate anti-Human sheep IgG (Sigma-Aldrich) diluted 1:1000 in

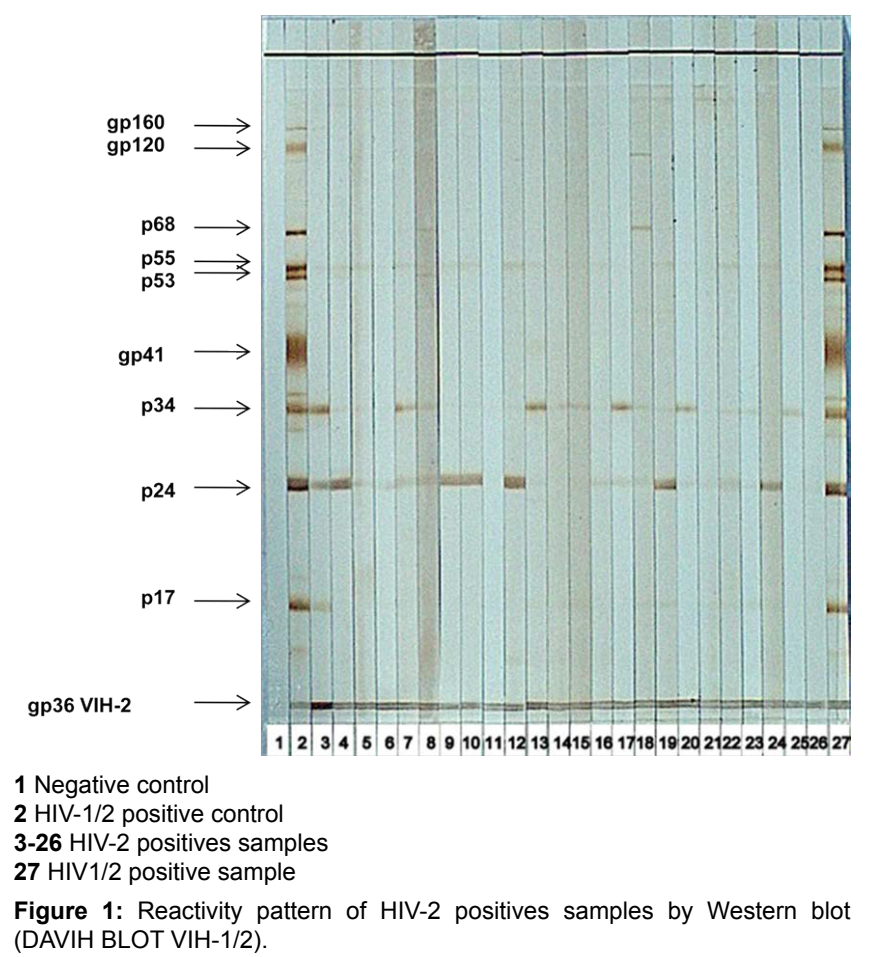

the same sample dilution buffer was added. After incubate one hour and washing, strips were developed with substrate buffer solution containing $0.08 \%$ hydrogen peroxide and the chromogenic substrate $0.05 \%$ diaminobenzidine tetrahydrochloride (Sigma-Aldrich, SL, USA). Finally, the reaction was stopped with distilled water when colored bands appeared (3-5 minutes).

In support of assay quality validation was considered that in the HIV-1/2 positive control serum, must appeared reactivity against corresponding bands to HIV-1 viral proteins (p17, p24, p34, gp41, p53/ p55, p68, gp120 and gp160) and to HIV-2 gp36 peptide band. In the negative control must not appear specific bands or only reactivity to HIV-1 p17. Was applied the WHO recommended criterion for HIV-1 interpretation, which a sample is considered positive if at least two of the three bands coded by the env gene (gp41, gp120 and gp160) are present, negative if no bands appear or only p17 and indeterminate when there is a band profile that does not classify as positive or negative. A HIV-2 positive result was considered when reactivity signal is equal or higher to gp36 control band and negative when it is lower or non-reactive to positive control serum.

\section{Results}

DAVIH-BLOT VIH-1/2 correctly identified all HIV-1 positives in reference panels for a $100 \%$ of diagnostic sensitivity as shown in Table 4. Diagnostic sensitivity to HIV-2 was also $100 \%$; an equal or higher signal to the peptide control band was obtained in all the thirty-three HIV2 positive samples analyzed. Reactivity of some HIV-2 positives sera against the peptide are shown in Figure 1. These samples also revealed indeterminate patterns to HIV-1, presenting reactivity against gag ( $\mathrm{p} 55$, p24 and p17), pol (p53 and p34) and env (gp160) gene proteins.

Diagnostic specificity was $67.74 \%$, as a result ten negatives samples which were classified as indeterminate for HIV-1. The HIV-1 positives sera revealed reactivity to HIV-1 natural proteins and only one was reactive to HIV-2 gp36 peptide. Therefore, analytical specificity was $99 \%$ for HIV-1 positives sera facing the HIV-2 peptide. Positive verisimilitude rate was 3.1 when it was analyzed reactivity of HIV-1

\begin{tabular}{|c|c|c|c|c|c|}
\hline \multirow{2}{*}{\multicolumn{2}{|c|}{$n=166$}} & \multicolumn{4}{|c|}{ Relation sample's condition to infection } \\
\hline & & HIV-1 Positive & HIV-1/2 Positive & HIV-2 Positive & Negative \\
\hline \multirow{5}{*}{$\begin{array}{l}\text { DAVIH-BLOT } \\
\text { HIV-1/2 }\end{array}$} & HIV-1 positive & 99 & 0 & 0 & 0 \\
\hline & HIV-1/2 Negative & 0 & 0 & 0 & 21 \\
\hline & Indeterminate & 0 & 0 & 0 & 10 \\
\hline & HIV-2 Positive & 0 & 0 & 33 & 0 \\
\hline & HIV-1/2 Positive & 1 & 2 & 0 & 0 \\
\hline & & \multicolumn{2}{|c|}{ HIV-1 proteins } & \multicolumn{2}{|c|}{ gp36 peptide } \\
\hline \multicolumn{2}{|l|}{ Sensitivity (\%) } & \multicolumn{2}{|c|}{100,0} & \multicolumn{2}{|c|}{100,0} \\
\hline \multicolumn{2}{|c|}{ Specificity (\%) } & \multicolumn{2}{|c|}{67,74} & \multicolumn{2}{|c|}{99,0} \\
\hline \multicolumn{2}{|c|}{ Rates of positive verisimilitude } & \multicolumn{2}{|c|}{3,1} & \multicolumn{2}{|c|}{100,0} \\
\hline \multicolumn{2}{|c|}{ Rates of negative verisimilitude } & \multicolumn{2}{|c|}{0,0} & \multicolumn{2}{|c|}{0,0} \\
\hline
\end{tabular}

Table 4: Comparison of the results of the DAVIH-BLOT system standardized for HIV-1/2 in front the reference panels.

\begin{tabular}{|c|c|c|c|c|c|c|}
\hline \multirow{2}{*}{\multicolumn{2}{|c|}{$n=25$}} & \multicolumn{5}{|c|}{ HIV BLOT 2.2} \\
\hline & & HIV-1 Positive & Negative & Indeterminate & HIV-2 Positive & HIV-1/2 Positive \\
\hline \multirow{5}{*}{ DAVIH-BLOT HIV-1/2 } & HIV-1 positive & 19 & 0 & 0 & 0 & 0 \\
\hline & Negative & 0 & 2 & 0 & 0 & 0 \\
\hline & Indeterminate & 0 & 0 & 1 (“O” group) & 0 & 0 \\
\hline & HIV-2 Positive & 0 & 0 & 0 & 2 & 0 \\
\hline & HIV-1/2 Positive & 0 & 0 & 0 & 0 & 1 \\
\hline
\end{tabular}

Table 5: Comparison between DAVIH-BLOT modified to HIV-1/2 and "HIV BLOT 2.2" systems (Genelabs Diagnostics, USA) with the "WWRB302 (M) BBI ${ }^{\circledR "}$ panel. 
positives sera facing HIV-1 natural proteins. Instead of, reactivity HIV2 positives facing HIV-2 gp36 peptide showed a positive verisimilitude rate of 100. Comparative study results between DAVIH-BLOT HIV-1/2 and "HIV BLOT 2.2" to the "WWRB 302 (M) BBI" panel are shown in Table 5. A very good concordance (kappa $=1$ ) was obtained. Relative sensitivity was $100 \%$ as HIV-1 as HIV-2 gp36 peptide. A HIV-1 positive sample belonging to group "O" was classified as indeterminate for both systems.

\section{Discussion}

This study demonstrates, that DAVIH-BLOT HIV-1/2 offers reliable results with reference panels from different geographical areas and in the comparative analysis with a commercial kit. The system showed $100 \%$ of sensitivity as HIV-1 as HIV-2. Previous evaluations to DAVIHBLOT system are similar to these results of diagnostic sensitivity of HIV-1 positives samples facing HIV-1 natural proteins [4]. Therefore, sensitivity obtained for HIV-2 positives samples in front of the peptide, confirms the results in a previous performance evaluation of gp36-BSA immobilized in nitrocellulose membranes [16], but a higher number of samples was used. Some authors used a similar number of samples and format to evaluate HIV confirmatory systems. In 2002, Lakshmi and Ponamgi [17], in evaluation of a HIV-1 Western blot with gp36 peptide, used $50 \mathrm{HIV}-1$ positives, $10 \mathrm{HIV}-2$ positives and $10 \mathrm{HIV}-1 / 2$ double reactive and also obtained a high sensitivity.

Other authors evaluated diagnosis systems of different format, but containing gp36 synthetic antigens, reported high sensitivity to these antigens, similar to this work. Kline et al. in 1996 [18], in the standardization and evaluation of a discriminatory system for HIV-1/2 used 215 positive serum samples to HIV-2 raising a 100\% sensitivity.

Several authors had reported high sensitivity too: Marcelino et al. in 2006 [19], in the evaluation of a specific HIV-2 ELISA with gp36 recombinant peptides tested 106 positive samples to HIV2. In the validation of "LiaTek HIV II" system for confirmation and differentiation of HIV-1/2, 22 positive samples to HIV-2 were used [20]. In the evaluation of the Inno-Lia system, one of the first kits based on synthetic peptides and recombinant proteins used 25 positive HIV-2 samples [21].

Positive samples to HIV-2 are common cause of HIV-1 WB indeterminate results. Cross reactivity may occur between antigens of gag and pol given by the high percentage of structural homology that exists between these viruses [22], which contribute to reduce the specificity of the WB for HIV-1 [18]. The reactivity of HIV-2 positive samples against HIV-1 env proteins is commonless. Some authors' raise for B subtypes of HIV-2, where seen cross reactivity more frequently, which generates false double positive results occasionally [23].

The results of specificity of negative samples with indeterminate reactivity by WB coincide with other authors who reported a high rate, with a predominance of the reactivity to p24 and/or p55 [17,2427]. The results of the low reactivity of the peptide to HIV-1 positive samples are similar to those obtained by other authors and confirm the high specificity of the sequence employed, compared with samples with antibodies that may cross react with gp36 peptide. Kline et al. 1996 [18], studied $481 \mathrm{HIV}-1$ positive sera in the evaluation of a test with similar characteristics and none showed reactivity against the gp36 peptide. Kannangai et al. in 2001 [24], in the evaluation and comparison of ELISA with a peptide of 11 amino acids of the gp36 and a PCR system for HIV-2, employed $30 \mathrm{HIV}-1$ sera and only one was reactive to the peptide. Marcelino et al. [19], in 2006 evaluated $95 \mathrm{HIV}-1$ positive sera using an ELISA system with the gp36 polypeptides and extracted $100 \%$ specificity. More recently, Qiu et al. [25] in 2009 analyzed 119 samples previously tested as HIV-2 positive by WB Genelabs HIV Blot 2.2, through an assay with synthetic peptides of HIV-1 gp41 and HIV-2 gp36 and obtained more than $99 \%$ of concordance with the Inno-LIA system.

Verisimilitude rates calculated for DAVIH-BLOT HIV-1/2 showed a high probability of classifying as positive the patients really infected and very low probability of obtaining a positive result in a healthy person. An HIV-1 positive result by the assay is 3 times more probable in an HIV-1 infected person than in other healthy. Whereas, a positive result to the gp36 peptide is 100 times more probable in an HIV-2 infected person than in other healthy. In other words, we demonstrated a high probability that both the positive results as negative in the system are correct for both viruses (HIV-1/2). The difference of both results is due to the specificity of negative samples in front of the HIV-1 antigenic proteins and the HIV-2 gp36 peptide present in the solid phase of the assay. In this case, more negatives samples reacted against HIV-1 proteins than the HIV-2 peptide.

It is important to emphasize that probabilities ratio offers the advantage that correlate the test sensitivity and specificity in only one index. Similar that occurs with sensitivity and specificity; it does not vary with the prevalence. This fact allows using it as comparison index among different tests for a same diagnostic purpose [13,14]. However, we must underline that a reactive result to HIV-2 peptide in the system, requires the definitive confirmation by other methods, agreeing as recommend WHO [28].

In the comparative study, the result of "HIV BLOT 2.2" coincides with DAVIH-BLOT HIV-1/2 according the pattern referred in the panel. DAVIH-BLOT HIV-1/2 revealed bands patterns that suggest positivity for HIV-1 positive sample belonging to group "O", because there was reactivity to all the bands, except to gp120/160. This result is due to the phylogenetic divergence between the viral strain used in the WB and the sample in question and coincides with studies of other authors that have included the "O" group [29,30]. An indeterminate pattern with these characteristics (high probability of being HIV-positive), in our algorithm requires follow-up and clinical epidemiological study to unravel the cause of reactivity [8].

Many authors report that the reactivity with indeterminate pattern by WB to HIV-1 is feature in positive samples to HIV-2 [31]. HIV-2 positives samples showed a high signal against gp36 peptide and indeterminate pattern with reactivity against HIV-1 proteins by DAVIH-BLOT HIV-1/2. In addition, the results of both systems coincide in a dual reactive sample, characterized as positive to HIV-1 according the reference data.

Double reactive samples to HIV-1/2 revealed the characteristic pattern of positive reactivity to HIV-1 and a high signal in the band of peptide, which showed that solid phase with the incorporated peptide, is not only capable of discriminating between the two infections, but also it has the additional attribute to diagnose a possible double infection by both viruses.

The system's advantages with the incorporated peptide, can be very useful for samples characterized as reactive in combined screening systems to HIV-1/2 and in Cuban infection control, where circulation of both viruses is reported [5-8]. In this way is possible to short out the diagnostic algorithm avoiding the use of a HIV-2 specific ELISA. The reactive samples to the peptide could be sending directly to confirmation by HIV-2 Western blot. 
Citation: Sui OC, Herrera DFD, Tamayo LM, Martínez KR, Guevara MTP, et al. (2013) Evaluation of DAVIH-BLOT System for Simultaneous Diagnosis of HIV-1/2. J AIDS Clinic Res S1: 020. doi:10.4172/2155-6113.S1-020

We consider appropriate the use of African and other geographical areas sera panels in our study, given that with this type of sample, sensitivity and specificity of the kit are challenged. This is convenient to obtain a competent diagnostic kit in order to confront some diversity of HIV positive samples in the population, so in circulation of several HIV-1 subtypes, HIV-2 or very rare groups such as "N" or "O" as possible, according other authors' recommendations [32].

\section{Conclusions}

DAVIH-BLOT HIV-1/2 system reached satisfactory results on performance indicators studied in front of the reference panel and in the comparative study with the commercial kit of similar principle. Nevertheless, evaluation doing in field with the new system should do in parallel with routinely diagnostic assays used in the country. If results are just good enough, the use of the diagnostic kit could be recommendable to confirm HIV-1 infection and a presumptive HIV-2 diagnosis simultaneously. This is appropriate when screening assays for HIV- 1 and 2 in the diagnostic algorithm are used.

\section{References}

1. Constantine NT (2006) HIV Antibody Assays. HIV InSite Knowledge Base Chapter Niel reagents of the University of California. The UCSF Center for HIV Information.

2. Chan L, Yin MF, Tay HS, Sum YW, Griffiths PJ, et al. (1991) Development of an augmented Western blot assay for characterization of samples reactive by combined HIV-1/HIV-2 screening assays. Int Conf AIDS 7: 124.

3. CECMED (2001) Regulación 8/2001 Requisitos generales para el registro de los diagnosticadores. Cuba.

4. Cruz O, Pérez M T, Izquierdo M, Lobaina L, Rubial I, et al. (1997) Evaluación de un sistema de Western Blot (DAVIH-BLOT) para la confirmación de anticuerpos al VIH-1. Rev Cubana Med Trop 49: 21-23.

5. González del Valle Z, Díaz HM, Vázquez A, Lubián AL, Álvarez A (2003) Infección por el virus de la inmunodeficiencia humana tipo 2. Presentación de un caso. Rev Cubana Med 42: 3.

6. Martín D, Silva E, Pérez MT, Díaz DF, Romero K, et al. (2007) Diseño y evaluación del sistema DAVIH VIH-2. Rev Cubana Med Trop 59: 1-6.

7. Díaz D F, Ortiz E, Martín D, Nibot C, Rizo A, et al. (2012) HIV-2 Antibody Detection after Indeterminate or NegativeHIV-1 Western Blot in Cuba, 20052008. MEDICC Rev 14: 25-29.

8. Díaz HM, Pérez MT, Lubián AL, Nibot C, Cruz O, et al. (2011) HIV Detection in Cuba: Role and Results of the National Laboratory Network. MEDICC Rev 13: $9-13$

9. Jacobson RH (1998) Validación de pruebas serológicas para el diagnóstico de enfermedades infecciosas. Rev Sci Tech Off Int Epiz 17: 507-526.

10. Ochoa RF (2004) Bases metodológicas para la evaluación de anticuerpos en ensayos clínicos de vacunas mediante técnicas inmunoenzimáticas. Ediciones Finlay Ciudad de la Habana.

11. CECMED (2007) Regulación 41/2007. Validación de métodos analíticos. Cuba.

12. WHO (1990) Acquired immunodeficiency syndrome (AIDS). Proposed WHO criteria for interpreting results from Western Blot assays for HIV-1, HIV-2 and HTLV-I/HTLV-II. Wkly Epidem Rec 65: 281-283.

13. Pita Fernández S, Pértegas Díaz S (2003) Pruebas diagnósticas: Sensibilidad y especificidad. Cad Aten Primaria 10: 120-124.

14. Dujardin B, Van der Ende J, Van Gompel A, Unger JP, Van der Stuyft $P$
(1994) Likelihood ratios: a real improvementforclinical decisión making? Eur J Epidemiol 10: 29-36.

15. OPS (Organización Panamericana de la Salud) (1994) Manual de Procedimientos de Control de la Calidad para los Laboratorios de Serología de los Bancos de Sangre, Washington DC, USA, 13-20.

16. Díaz DF, Cruz O, Montano L, Silva E (2011) Evaluation of the immobilization of one HIV-2 gp36 peptide in nitrocellulose membrane. Rev Cubana Med Trop 63.

17. Lakshmi V, Ponamgi SP (2002) Evaluation of an indigenous Western blot kit for human immunodeficiency virus. Indian J Med Microbiol 20: 200-205.

18. Kline RL, McNairn D, Holodniy M, Mole L, Margolis D, et al. (1996) Evaluation of Chiron HIV-1/HIV-2 recombinant immunoblot assay. J Clin Microbiol 34: 2650-2653.

19. Marcelino JM, Barroso H, Gonçalves F, Marques SS, Novo C, et al. (2006) Use of a new dual-antigen enzyme-linked immunosorbent assay to detect and characterize the human antibody response to the human immunodeficiency virus type 2 envelope gp125 and gp36 glycoproteins. J Clin Microbiol 44: 607611.

20. Zaaijer HL, van Rixel GA, Kromosoeto JN, Balgobind-Ramdas DR, Cuypers $\mathrm{HT}$, et al. (1998) Validation of a new immunoblot assay (LiaTek HIV III) for confirmation of human immunodeficiency virus infection. Transfusion 38: 776781.

21. Pollet DE, Saman EL, Peeters DC, Warmenbol HM, Heyndrickx LM, et al. (1991) Confirmation and differentiation of antibodies to human immunodeficiency virus 1 and 2 with a strip-based assay including recombinant antigens and synthetic peptides. Clin Chem 37: 1700-1707.

22. Syed IH, Balakrishnan P, Solomon SS, Murugavel KG, Kumarasamy N, et al. (2005) HIV-1 Western blot assay: What determines an indeterminate status? Indian J Med Sci 59: 443-450.

23. Damond F, Apetrei C, Robertson DL, Souquière S, Leprêtre A, et al. (2001) Variability of human immunodeficiency virus type 2 (HIV-2) infecting patients living in France. Virology 280: 19-30.

24. Kannangai R, Ramalingam S, Prakash KJ, Abraham OC, George R, et al. (2001) A peptide enzyme linked immunosorbent assay (ELISA) for the detection of human immunodeficiency virus type-2 (HIV-2) antibodies: An evaluation on polymerase chain reaction (PCR) confirmed samples. J Clin Virol 22: 41-46.

25. Qiu M, Liu X, Jiang Y, Nkengasong JN, Xing W, et al. (2009) Current HIV-2 diagnostic strategy overestimates HIV-2 prevalence in China. J Med Virol 81: 790-797.

26. CDC (1989) Interpretation and use of the Western blot assay for serodiagnosis of human immunodeficiency virus type 1 infection. MMWR 38: 1-7.

27. Uneke CJ, Alo MN, Ogbu O, Ngwu BAF (2007) Western blot-indeterminate results in Nigerian patients HIV serodiagnosis: The clinical and public health implication. AIDS PatientCare and STDs 21: 169-176.

28. WHO (2007) Guidance on provider-initiated HIV testing and counselling in health facilities.

29. McCutchan FE (2000) Understanding the genetic diversity of HIV-1. AIDS 14 S31-S44.

30. Oelrichs RB (2004) The subtypes of human immunodeficiency virus in Australia and Asia. Sexual Health 1: 1-11.

31. Tebourski F, Slim MA, Elgaaied A (2004) The significance of combining World Health Organization and Center for Disease Control criteria to resolve indeterminate human immunodeficiency virus type-1 Western blot results. Diagn Microbiol Infect Dis 48: 59-61.

32. Thorstensson R, Andersson S, Lindback S, Dias F, Mhalu F, et al. (1998) Evaluation of 14 commercial HIV-1/HIV-2 antibody assays using serum panels of different geographical origin and clinical stage including a unique seroconversion panel. J Virol Methods 70: 139-151. 